Modern Asian Studies 4o, 1 (2006) pp. 175-201. (C) 2006 Cambridge University Press doi:10.1017/S0026749X06001946 Printed in the United Kingdom

\title{
Children, Emotion, Identity and Empire: Views from the Blechyndens' Calcutta Diaries ( I 790-I822)
}

\author{
PETER ROBB
}

\author{
School of Oriental and African Studies, London
}

The voluminous Blechynden diaries, in the British Library, offer incomparable opportunities for studying (among other things) domestic life among middle-level British residents of Calcutta around the start of the nineteenth century. This paper is concerned with a small part of the history of the Blechynden household, focusing on Arthur Blechynden, son of Richard and his successor as superintendent of roads. ${ }^{1}$ Richard's diary runs to more than 70 volumes and Arthur's to seven. These sources permit none of the structural analysis that was made the basis of family history by Peter Laslett and others; but they touch several points of the richer canvas painted by Laurence Stone, and those genres that are concerned with individual lives, with emotion, with relationships, and with identity, the kinds of subject approached by the contributors to Roy Porter's collection Rewriting the Self. ${ }^{2}$ In this paper some of these issues will be taken up, with particular reference to ideas of individuality and of race. That discussion will then lead on to another, on the construction of British

${ }^{1}$ This paper was prepared for David Washbrook's seminar at St. Antony's College, Oxford; my thanks for the comments of the participants. I am grateful also to the AHRB for a grant in support of the research. The main source is Arthur Blechynden's diary (1807-12), at the British Library, Add. Mss. 45654-61 (hereafter 'AB'). Elsewhere I have described Richard Blechynden's huge and important diary (17911822), Add. Mss. 45581-653 (cited here as 'RB'); see Peter Robb, Clash of Cultures? An Englishman in Calcutta in the I 790 os (SOAS, London 1998), and 'Credit, Work and Race in Calcutta in the 179 os: Early Colonialism through a Contemporary European View', Indian Economic and Social History Review 37, 1 (2000). Only limited references will be given to the diaries if points derive from multiple entries.

${ }^{2}$ See Peter Laslett, ed., Household and Family in Past Time (Cambridge 1972); Laurence Stone, The Family, Sex and Marriage in England I50o- I 800 (1976; abridged ed., London 1979); Roy Porter, ed., Rewriting the Self. Histories from the Renaissance to the Present (London and New York 1997).

oo26-749X/o6/\$7.50+\$0.10 
imperial identity outside Britain and in the context of the formation of empire, an aspect that seems worthy of more attention than it has received. ${ }^{3}$

\section{Emotion and duty}

Arthur Blechynden was born on 7 February 1 79o, Blechynden's eldest son by a concubine or bibi never named in the diaries. She would have several more of Richard's children, and die from complications of child-birth. A Hindustani Muslim, as far as can be ascertained, she was buried in the grounds of the boys' charity school that Richard supported, with its pandit, near his garden house. Upkeep of the grave was provided for, in his will, decades later.

Arthur and his siblings added to the large number of mixed-race children born as a result of European incursions into India from the time of the Portuguese. By the late eighteenth century such IndoPortuguese provided many of the slaves and servants of European Calcutta, ${ }^{4}$ but British offspring too were already numerous. According to Christopher Hawes' study, half the children baptised at St. John's

${ }^{3}$ For example in Linda Colley, Britons. Forging the Nation, I 7o7- I 837 (New Haven \& London 1992), though see pp. 169-70, on 'civilizing' Indians and the divine purpose of empire, topics for the Cambridge prize essays of 1804. Despite some attempts to 'write about individuals and groups who were believed by large numbers of people to represent what was best in the Empire'- the quotation is from Kathryn Tidrick, Empire and the English Character (London 1990), p. 2, a book avowedly on individuals not ideas-the tendency has been to focus on the effects of the British on others rather than the other way round. See, for example, J. A. Mangan, ed., Making Imperial Mentalities. Socialisation and British Imperialism(Manchester \& New York 1990), though the series prospectus (written by John McKenzie) spoke, like some of McKenzie's own work, of 'profound effects on dominant as well as on subordinate societies' (p. ix). Gyan Prakash raised the question (if the 'native' was constituted by colonial rulers, surely s/he 'exercised a pressure on the identification of the colonizer'?), but overlaid it with a welter of issues: self-other, dislocationtransformation, universality-relativism; see Prakash, ed., After Colonialism. Imperial Histories and Postcolonial Displacements (Princeton 1995), p. 3. The notable exception to this neglect, especially for the early imperial period, is Peter Marshall's work, from his inaugural lecture, 1981 , to his four presidential addresses to the Royal Historical Society, 1998-indispensable background for this article. See P. J. Marshall, 'A Free though Conquering People' (London 2003).

${ }^{4}$ On Luso-Indians, see Holden Furber, Rival Empires of Trade in the Orient, I6ooI80o (1976; Delhi 1990), pp. 322-4; despite his description of their status and occupations earlier and elsewhere, disrespect for the 'Portuguese' (whether Eurasian or not) did exist in 1790 Calcutta. 
in the 178 os were of mixed parentage, while one in three wills made bequests to Indian companions and/or their children. ${ }^{5}$

When Arthur was a small child, financial and other complications meant that he was brought up in a small house adjoining his father's rooms in town-brought up very largely by his mother and her servants. ${ }^{6}$ Bibis were admitted to the company of men, but not with propriety to that of married women; nor were they supposed to be seen with their men in public; these were matters on which Richard Blechynden was particularly strict. The result was that his bibis (who were paid) occupied their own world, exchanging visits with other bibis and their families, even engaging in their own businesses. Richard seldom interfered with their autonomy or their management of the babies, though from time to time he would disapprove of the food the children ate or the time they spent in the sun. ${ }^{7}$

He asserted himself, obviously, over his children's names (which were not just English but in some cases meaningful in family terms), and he had them Christened and inoculated against smallpox, as was the custom. When unable to treat them himself, he called a European doctor to tend their illnesses; or sometimes the bibi did so on her own initiative. At other times he was recalled from his work or wakened in the night to deal with his feverish and teething children. ${ }^{8}$ Gradually, therefore, out of their quasi-Indian environment, the children came to be socialized into their father's circle also; unlike their mother, they did not have to be invisible. They visited neighbours and were clucked over by visitors-Arthur was a 'very pretty child much petted' by such guests. ${ }^{9}$ The children and their mother would come to the garden house and spend weekends en famille, or with house parties of male friends and sometimes their Indian female companions as well. While still very young Arthur accompanied his father when he went to shoot birds for the table, or when he and friends went bathing in his or a neighbour's tank. Soon he was sent to a school. (Richard also arranged schools for the children, girls as well as boys, of friends

${ }^{5}$ Christopher Hawes, Poor Relations. The Making of a Eurasian Community in British India, I773-I833 (Richmond, Surrey, 1996), p. 4 and passim.

${ }_{7}^{6} \mathrm{RB}, 7$ April 1794 .

${ }^{7}$ For comments on the children's upbringing by their mother and concerns over their health, see for example RB, 28 November 1 793, 2 \& 4 March 1 794, 31 January $1795,18,19,20 \& 23$ March 1795, and 27 \& 28 April 1795.

${ }^{8}$ For example, RB, 2 March 1794.

${ }^{9} \mathrm{RB}, 29$ and 31 July 1794. 
stationed outside Calcutta. ${ }^{10}$ When Arthur was not yet five, his father also began to plan to send him to England, as soon as he could afford it. ${ }^{11}$ Arthur left eventually in July 1797 , aged seven. In such matters, Richard seems entirely ordinary. He might as well have been modelling himself on George III at the height of his domesticity, though he never mentions the example, and, given when he arrived in India, may not have been particularly aware of it.

Firstly, Blechynden repeatedly recalled that he had a duty to provide for his children and their education. In later, more prosperous years, this became an excuse not to marry but instead to retain a succession of bibis-Indian, Eurasian and European. Wives were expensive and legitimate children would have a greater claim to his inheritance. Obviously, too, English knowledge and background would aid Arthur's employment in a British colony; but also it was a patriarchal choice. Richard asserted his rights, if necessary against the children's mothers. In later years, he was beset by troublesome bibis. Though he died just too early to have seen that guide to choosing a companionable and above all domesticated wife, published by William Cobbet in 1829 , he spent much of his life seeking in vain for 'proper' treatment, as he regarded it, from a succession of spirited and sometimes alcoholic ladies. He was never short of the advice of friends, however, and at their urging he repeatedly considered and sometimes succeeded in cutting himself off from his more violent and unreliable companions. In these dramas, he would soften at the thought of depriving the mother of her children and the children of their mother, and also in reaction to the shame a cast-off mother might bring to the children, if forced into prostitution. But not once did he consider giving up the children. He even temporarily demanded to keep a baby whom a servant girl claimed was his. (She later admitted it was not.) Several times he took legal advice, and it reassured him, as would be expected, about his 'guardianship by nature', a right vested in the male even for married couples, in accordance with general British expectations in common law and at equity. ${ }^{12}$ On the other

${ }^{10}$ For example, for the illegitimate daughters of his acquaintance, Berkeley; RB, 1 August 1794 .

11 RB, 21 January 1795.

${ }^{12}$ This remained so in England at least until the changes in 1839 (possible custody of children under seven for non-adulterous divorced wives) and $185^{8}$ (judicial divorce), that led on to the Married Woman's Property Act of 1882 and the Matrimonial Causes Act of 1884. Arguably it remained so until the Guardianship of Infants Act of 1925, with its emphasis on the welfare of the child. 
hand, Blechynden reflected that the law gave his children's mothers few rights, and that he had power over them like a creditor's over a debtor-as judge, jury and executioner. Any such relationship was a contract and often his mistress had not kept her part of the bargain, and yet (he reasoned with himself) 'the less the law protects a feeble woman the more considerate' a man had to be. ${ }^{13}$

Secondly, Blechynden was undoubtedly attached to his children, in partly-sentimental ways that also were common by these times. $\mathrm{He}$ fretted over their illnesses, and thought seriously about and invested in their future. True, the concern was not always overt. For example, the birth of his daughter Sarah, called Sally, on 21 November 1792 produced no further comment in the diary, and other arrivals were scarcely more elaborately noticed; anniversaries too were often very casually marked, as for that matter were Christmas and other festivals. Moreover, when his baby son Sidney died in March 1793 and he had no way of returning to Calcutta from Serampore, Blechynden merely sent a chit so as to secure an undertaker who had advertised cheap funerals. On the other hand, that night he wrote: 'I could not compose myself to rest, thinking of the child' and worrying about the funeral arrangements and so on; true, the death was a 'very happy release' for one who had always been ailing, but for that he blamed the very bad wet nurse, taken on because the mother would not suckle the child. ${ }^{14}$ This was a diary-entry typical of many others that reflect rather than express or analyse his agitation. In blaming the wet-nurse and indirectly the mother, he was echoing the perennial opinion of experts in Britain, if not the upper-class fashion; ${ }^{15}$ but he was also revealing his emotional state, the thoughts going through his mind as he tried to sleep. Similarly, Sidney's mother was distraught, and accused a servant of beating the child to death. The doctor concluded he had died from convulsions brought on by teething. ${ }^{16}$

Laurence Stone claims that high mortality rates forced parents to limit their emotional involvement with infants-and cites one case from the 1770 s of a mother, devoted to her older children, who hardened her heart against a sickly baby thought unlikely to survive. ${ }^{17}$ Infant death-rates began to fall in Britain after the $175^{\text {os, but }}$

${ }^{13}$ RB, 10 July 1810.

14 RB, 9 March 1793 .

15 Stone, The Family, pp. 269-73.

${ }^{16} \mathrm{RB}, 11$ and 12 March 1793.

17 Stone, The Family, p. 57. 
anecdotal evidence suggests that that was far from true in Calcutta even for well-to-do European families, though its European doctors adopted improved obstetric techniques, and smallpox inoculation was wide-spread (factors associated with the improvements in Britain). ${ }^{18}$ Certainly Blechynden's record of his response to Sidney's death showed his emotion, but also that he did not dwell on the tragedy-very much his stance as he followed the frequent funeral processions for his adult acquaintances. On the other hand, his general attitude towards his children reveals that the greater closeness of families, noted from the eighteenth century onwards, also applied in some measure to this mixed-race household in Calcutta, except of course that the mother was a kind of employee (or more formally so than a wife would have been).

Blechynden's parental concern was expressed sometimes as conventional hopes for the future, spiced with conventional pleas to the deity, and sometimes as understated feeling; but also at times directly. On the eventual departure of both Arthur and Sally for England he found himself quite overcome, going over the arrangements in his mind, repeatedly picturing their progress down the river and across the seas, fearing for their safety. A constant concern for the welfare of all his children, and a keen appreciation of their qualities, good and bad, ran through his diary to the end. Clearly most other parents agreed, though not quite all. When Blechynden's friend, Richard Ecroyd, was considering sending his half-sister to England, when she was 13, her mother, Mrs Maxwell, demurred: the girl would be too old to go to school, and was already too old to travel safely amongst sailors. She wanted her with her, the more so as she already had four or five children in Europe who never wrote and did not propose to return. Ecroyd prevailed, however. ${ }^{19}$

Sending his children to England was a mark of Blechynden's attachment, and not a denial of it. There was nothing at all remarkable about sending children away, nor (contrary to some accounts) was it peculiar to British people in India or solely a reaction to social and geographical distance. From at least $15^{\circ}$ o, according to a source cited by Alan Macfarlane, a majority of English children had been sent from home at an early age, between 7 and 10, to boarding schools, or to work as servants or apprentices, often for other families of similar rank. Macfarlane was studying a seventeenth-century cleric,

${ }^{18}$ Ibid, p. 59 .

${ }^{19}$ RB, 17 \& 18 January 1793 \& 25 February 1795 . 
Ralph Josselin; it is interesting that despite this custom he found regular contacts and even emotional ties within the family. ${ }^{20}$ But Stone concludes unsurprisingly that the practice diminished the ties of affection between children and parents, and he is also pessimistic about the prevalence of romantic love. On the other hand he describes the greater 'ease and warmth' emerging in the eighteenth century. ${ }^{21}$

As I have discussed elsewhere, Blechynden was certainly warm enough in his relations with women, but his involvement with the children, by letter and then after their return to India, was of a quite different quality. He had a strong family sense, which I think derived from his own experience. According to Stone, there is evidence, at least in higher social groups, of strong ties between siblings, especially brothers and sisters from the eighteenth century. ${ }^{22}$ Blechynden, an orphan, also made repeated protestations of affection and gratitude to his aunt and uncle in England, the Theobalds, who had supported him as a child, and to whom he wrote often; and he very frequently lamented the fate of his dear sister (lost in the wreck of the Grosvenor) ${ }^{23}$ He assumed that his relatives would care for his children in England, as a duty and not only in return for the remittances he sent them-just as he brought into his own household Tom, the illegitimate son of his dead cousin Marmaduke, having reclaimed him from the care of the latest partner of the boy's mother, after her death. Arthur was taken in by the Theobalds in Great James Street, near Gray's Inn, and afterwards by another aunt, Mrs Whitechurch of Bramley in Hampshire, who (he said) taught him English.

Such broad familial responsibility was not only common, it was unavoidable. Another example will remind us why. It relates to Colonel Robert Kyd, founder of the Calcutta Botanic Garden, and his relative and heir, Major Alexander Kyd. A cousin of Robert's was a navy captain in East India service. His son, Sandy or Alexander, had arrived in Calcutta in 1772 without employment but with a letter of introduction to Robert Kyd. But Robert decided (he wrote to his cousin in Fifeshire) that Sandy should be sent back on the first ship, because in the changing circumstances of India there was no choice but that he should enter the army; which should be after he had qualified as an engineer

${ }^{20}$ Alan Mcfarlane, The Family Life of Ralph Josselin. A Seventeenth-Century Clergyman (Cambridge 1970), especially Part III.

${ }^{21}$ Stone, The Family, p. 80; see also ch. 7, esp. pp. 190-1.

${ }^{22}$ Ibid., pp. 81-8.

${ }^{23}$ See Stephen Taylor, The Caliban Shore: the Fate of the Grosvenor Castaways (London 2004). 
and artillery officer, and above all (using all the influence his father could bring to bear) once he had gained an ensign's commission. To achieve this, Robert provided Sandy with money sufficient to cover his expenses for two years, and also introduced him to friends who, 'in case of any accident happening to myself, will receive and provide for him in a manner next to what he would have expected from myself'. Indeed, before taking it upon himself to devise this 'startling' plan, Robert had consulted his friends, who supported his judgment. This exemplifies the expectations, in a world based on patronage, of the duties of relations and the part to be played by connection. Alexander, who was to have a successful career as an army engineer, retained a keen sense of his debt. After his cousin's death in 1793 he commissioned a memorial to be designed and built by Richard Blechynden, incorporating an imported urn by Thomas Banks, the neo-classical sculptor. This was the same Alexander, incidentally, who was father to the Anglo-Indian Kyd brothers who were close friends of the Blechyndens, and who (with their father's backing) developed the famous dockyards at Kidderpore. ${ }^{24}$ The code of conduct here is very plain, as also when Alexander helped Blechynden during his greatest financial crisis, and Richard marvelled at his 'innate generosity', doing so much for someone who was 'no relation': 'What claims have I on Major Kyd,' he wrote, '... that should entitle me to put my hand in his purse?'25

In his plans for his children Richard Blechynden was again unremarkable; which is interesting in itself, given the irregularity he himself perceived in his domestic circumstances. The children were after all Eurasian; yet Blechynden-who was quite aware of skin colour in others-seems hardly to notice the fact. When musing on sending Arthur to England, he reflected: 'surely my relations must have more liberality of sentiment than to refuse to notice him because he is illegitimate- that is not his fault it is mine'. ${ }^{26}$ When Sally had her face savaged by a dog, he was saddened at the likely permanent blemish, which would be hard, he thought, 'particularly in an illegitimate child'. ${ }^{27}$ Indeed, daughters were said to be more of a problem. At least in higher social circles, it seemed that, as Lord Mulgrave put it in

${ }^{24}$ Robert to James Kyd, 28 February 1773, reproduced in A Short Account of Colonel Kyd, the founder of the Royal Botanic Garden, Calcutta (Calcutta 1893), reprinted from Vol. IV of the Annals of the Garden.

${ }^{25} \mathrm{RB}, 23$ July 1795 .

${ }^{26} \mathrm{RB}, 21$ January 1795.

${ }^{27} \mathrm{RB}, 4$ March 1795 . 
the Lords, in 1800 , 'bastardy is of little comparative consequence to the male children' ${ }^{28}$ In that case what was the point of sending the children to England? It was for same reason they had English names and an English baptism. It was to make them English. But could it be done?

\section{Making individuals}

In believing that an Englishman could be made, Blechynden obviously followed Locke in his ideas of human development, ${ }^{29}$ without noting it explicitly. Already one could see this in his view of the educational dangers of beating. It was to Mr Purchase's school at 6 rupees a month that Arthur was entered as a day boy, aged four and a half. A few days later he was reluctant to return. Blechynden wrote at once to Purchase to warn him that Arthur 'must not be corrected as it might have a very disgraceful effect on his riper years from the aversion he might take to his book'. ${ }^{30}$ Add doubts over the usefulness of learning by fear, and this instruction was an echo of Locke's Treatise on Education, published in repeated editions from $1693 \cdot{ }^{31}$ Despite the apparently growing popularity of pornography that featured flagellation, ${ }^{32}$ educational practice was becoming somewhat less brutal than before, during the eighteenth century, as reflected in James Nelson's mid-century guide to child rearing. ${ }^{33}$

More significantly, Blechynden clearly subscribed to the notion of the self as a product of education and experience, as proposed in Locke's Essay on Human Understanding. Why else send half-Indian, Indian-reared children to England at an early age, condemning them to learn Bengali as a foreign language on their return? As a consequence of this emphasis on nurture, Blechynden constructed his view of childhood around notions of shelter and direction. This was not a prudish society, for all the rules and conventions that sought to make its blemishes unseen, hiding malfeasance, violence and fornication, as it were, under powder and wig. Stone quotes Le Rochefoucauld writing

${ }^{28}$ Stone, The Family, p. 331.

${ }^{29}$ For a convenient summary of the theoretical options, see ibid., pp. 254-6.

${ }^{30} \mathrm{RB}, 1$ \& 11 August 1794 . He was withdrawn on 7 May 1795.

31 See ibid., pp. 279-80.

${ }^{32}$ See Julie Peakman, Mighty Lewd Books: the Development of Pornography in Eighteenthcentury England (Basingstoke 2003), chs. 6 and 7.

33 Stone, The Family, pp. 274-5. 
in 1784 of the great freedom among the English in talking about highly indecent subjects, and, rather charmingly, speculates that he must have meant among the men, after the ladies had withdrawn (an English and not a French custom). ${ }^{34}$ Perhaps, I would say; but not in Calcutta. Though Blechynden reserved high indignation for men who made love to other men's wives-in England it was said they were fair game if married to 'unsuitable' husbands ${ }^{35}$-, he lost no time in swapping ribald jokes at the dinner table with the new 14-year-old wife of his then employer, Eduardo Tiretta, aged 67, jokes referring to Tiretta's likely sexual incompetence. Indeed that was a subject on which Blechynden also reflected more seriously, thinking of the passage of years. He was an advocate of the old doctrine of sexual release-what Stone has called the plumber's view of the body ${ }^{36}$-as a necessity for himself, but apparently also a boon for women.

Nonetheless, if education were to form personality, childhood had to be a protected space. That was desirable anywhere, but imperative amidst the dangerous corruptions of India, corruptions that reflected the famed barbarity of the East (transmuted from an earlier discourse of monsters, so Dorothy Figueira claims), ${ }^{37}$ but more particularly the barbarousness of Europeans in the East. Such contamination proved the influence of experience on personality, and also justified fears for the young. Blechynden was appalled, for example, at stories of indecency with Mrs Tiretta's younger sister, and, on also being told that she was 'in love' with him, retorted that she should be sent to school and taught music, dance and accounts. ${ }^{38}$ He was aghast when an acquaintance, John Da Costa, asked for a copy of John Cleland's Woman of Pleasure, which since its appearance in 1749 had been the most celebrated pornographic text produced in England. He was aghast because Da Costa had said it was 'the best book that could be put into the hands of a young person just arriving at puberty'. Blechynden railed against such a risk to morals and health; he believed a father should 'stifle vicious sentiments as long as possible'. ${ }^{39}$

${ }^{34}$ Ibid., p. 325 .

${ }^{35}$ Ibid., p. 330 .

36 Ibid., pp. 312-19.

37 Dorothy Fugueira, 'Civilization and the Problems of Race; Portuguese and Italian Travel Narratives of India', in Balachandra Rajan and Elizabeth Sauer, eds., Imperialism. Historical and Literary Investigations, I500-I90o (New York \& Basingstoke 2004).

${ }_{38} \mathrm{RB}, 15,19 \& 23$ October 1793 .

${ }^{39} \mathrm{RB}, 28$ August 1793 . 
Hence his ambitions for his own children were essentially moral. He wanted Arthur to assist and succeed him, it is true, but, on his merits, after serving his apprenticeship. More important were probity and the avoidance of vice. Richard hated the thought of teenaged Arthur going to a nautch. (He went and declared himself disgusted.) Richard had been horrified when Arthur returned to India sooner than expected (having joined an earlier ship) and walked unrecognised into the house his father was sharing with his current bibi. He had planned to set her up in a separate establishment. Otherwise he feared undoing a costly and Christian education by exposing his son to, by flaunting in his face, the regrettably lower standards of Calcutta and himself. Too late-and so the boy was fated instead to become a kind of adviser to both parties and even a go-between, in the long and torrid unravelling of the relationship. It brought him even closer to his father, as a confidant as well as a son, something again that was common enough at the time. ${ }^{40}$

All was not lost, though, as Arthur proved himself firmly English, and as principled as-perhaps even more priggish than-his father. There were temptations: a servant tried to get into his bed more than once, threatening him with exposure if he did not comply with her wishes, but Arthur saw her off with resolve and shouting. Above all, even as a consequence, his own diary began with a summary of his life that entirely failed to mention his mother or to acknowledge his mixed ancestry. He resorted to innumerable excuses and downright refusal when one of her successors tried to involve him in annual ceremonies at her grave-side. The trick had been done, and he was an Englishman to himself, if not unequivocally to Calcutta. He attributed his character to his father and his education in England, and constantly reminded himself of the merits and benefits of both. ${ }^{41}$ It was a double English inheritance, but also it was honed by his experiences in Calcutta after his return. He emphasized 'industry and honesty' ${ }^{42}$ as we shall see, and a somewhat vague humanism. Witnessing a hook-swinging ceremony in Calcutta, he remarked, with a seventeen-year-old's conviction, that it was a sight to disgust someone 'just come from England' who would 'hardly believe that a civilized nation could invent these tortures for the sake of pleasing God'. Indians claimed superiority, he said, but

\footnotetext{
${ }^{40}$ See Stone, The Family, pp. 259-6o.

${ }^{41}$ For example, AB, 2 June 1811.

${ }^{42} \mathrm{AB}, 1$ January 1807 .
} 
their 'pre-eminence' is 'only in their speech, for their acts disgrace human nature'. ${ }^{4}$

In rejecting India and his Indian half, Arthur made of himself an autonomous individual, a process that was culturally-specific and related to a particular value-system. ${ }^{44} \mathrm{He}$ followed his father in this as in other things. Self-awareness was manifestly something for which Richard Blechynden did not always have the vocabulary but which he nonetheless achieved as one part of a broader prospectus. For he considered himself a man of rationality and science. While undertaking translations for the French traveller Pierre Sonnerat, he criticised him heartily for ridiculing the whole Newtonian system. ${ }^{45}$ He respected Belidor, his guide to hydraulic engineering, as much as Palladio, his model for architecture. He owned a set of Buffon's natural history. I do not know that he saw any difference between the principles of engineering and of aesthetics, or that he worried at all about principles of taxonomy. But certainly he lived in an age when humanism and the scientific revolution had affected the way people thought.

On one hand, humanism, especially in rediscovering the classical, spoke to a constant inherent universal. Blechynden greatly admired Sir William Jones whose work on Indo-European might be considered to embody that principle. On the other hand, the scientific revolution ultimately sought practical knowledge that would control and change the world, not understand it philosophically. ${ }^{46}$ Whereas Aristotelian syllogisms depend on the prior acceptance of a first premise that is taken to be universal (from common experience), modern science, after the seventeenth century, looked to individualized experiments in order to form and limit general rules.

This shift in emphasis between deductive and inductive science, as others have remarked, also affected the popular sense of self. To regard human nature as being derived from or subject to experience was, as Peter Burke argues, one (and not the only) kind of self-consciousness,

$43 \mathrm{AB}, 11$ April 1807 . In the hook-swinging ritual, devotees swung from a pole suspended on ropes to which they were attached by means of metal hooks passed through the muscles of their backs.

${ }^{44}$ Stone, The Family, p. $15^{1}$. Stone's chapter 6 contains much on the growth of affective individualism and its broader intellectual and social context.

${ }^{45}$ It is not clear which work Blechynden was translating for Sonnerat who was then in Calcutta. His celebrated Journey to the East Indies and China had been published in 1782 .

${ }^{46}$ See Peter Dear, Revolutionising the Sciences: European Knowledge and its Ambitions I500-I700 (Basingstoke 2001), esp. pp. 168-70. 
and it was associated in Europe with the Renaissance, with authorship, portraiture, autobiography, and particularly travel. The problem of the others encountered on journeys was of course writ large for Europeans who travelled and lived in India, even though they sought to make India familiar to them in many ways and to subordinate it to their own system of ideas. Experiment, exploration and empire all required unfamiliarity, which reinforced the need to develop inductive methods, to reach out towards universal rules by explaining what was not known, rather than by generalizing from experience. Norbert Elias links the change also to the development of centralized states and to material culture: printed books, mirrors, personal artefacts, and so on. ${ }^{47}$ These too were the everyday experience of people in Calcutta as it became the seat of a bureaucratic, regulated government, and one of the major urban centres of the world.

Blechynden made measurements, for example astronomical observations to correct clocks and watches, and he also conducted experiments, such as when dosing sick animals. In keeping a diary, he became engaged in a kind of observation of himself. As has often been remarked, a diary was in itself a mark of introspection, of what David Riesman called the separation of the 'behaving and scrutinizing self'. ${ }^{48}$ Blechynden was consciously, indeed artfully, preserving and reflecting on his life as narrative. He began his diary, he said, as a record of agreements and obligations: an aide memoire on debts, contracts and so on. But this prosaic purpose was very quickly overtaken by subjective elements, by domestic events, emotions and illnesses. When he encouraged Arthur to keep a diary, clearly he regarded the process as both therapeutic and improving. ${ }^{49}$

It was Gandhi who referred to his autobiography and his life as an experiment, but some such idea of the self has a much longer history. As the Duke pronounced in Measure for Measure, 'Spirits are not finely touched but to fine issues'-which means not only that

${ }^{47}$ See Peter Burke, 'Representations of the Self from Petrarch to Descartes', in Porter, Rewriting.

${ }^{48}$ David Riesman, The Lonely Crowd (abridged edn., New Haven 1961), p. 44; quoted by Mcfarlane, Josselin, p. 5, and Stone, The Family, p. 153. The growth in diary-writing from the late sixteenth century is variously attributed-by Mcfarlane, following Riesman, to changes in education and from oral to literary culture, to religious introspection, and to household accounting.

${ }_{49}$ The model, according to Arthur, was Lord Chesterfield, presumably in his Letters to his Son (1774), the advice being to note anything he would like to read after 3o years. 
virtues need to be expressed in actions, but also that it is actions which create them. One trial by experience is particularly apt for the present discussion, that of Shakespeare's Othello. In his final speech, Othello recognizes his errors and discovers his 'true character', which, by virtue of that self-knowledge, becomes effectively that of a Venetian or a Christian crusader. In that form he smites and kills his other, Moorish self, the 'circumciséd dog'. The hope was that Arthur would be similarly and, metaphorically-speaking, no less violently reformed by English experience. The idea of the 'test' as both a measure and a maker of character had continued as an eighteenth-century commonplace. In Mozart's operas, for example, it is most obvious in Schikaneder's quasi-Masonic rituals for Magic Flute but it is also apparent in the self-revealing flirtations of Da Ponte's Cosi Fan Tutte or the ordeal contrived for the Count in his Figaro; Don Giovanni's refusal to learn is his undoing. Within such plots, the self was being constructed in Locke's sense. In Cartesian terms, this is the difference between human awareness as intrinsic to a thinking being and as derived actively through the continuous process of thinking. In the latter case, of course, memory is vital to recover the self from moments of self-awareness: hence the importance of the diary. Rousseau, whose notion of human nature in Emile is arguably just the mirror image of Locke's, set out the position at the start of his Confessions: 'This is what I have done, what I have thought, what I was'. By being sent to England, Arthur too was being tried, and thus given the best chance to make himself.

The question of acquired versus intrinsic character is also at the heart of the encounter of Indian and European. For example, consider the reactions to environment. ${ }^{50}$ Mark Harrison has written interestingly about the relationship between climate and race. ${ }^{51} \mathrm{He}$

\footnotetext{
${ }^{50}$ See the discussion of Enlightenment thought, especially Diderot's views (responding to Raynal's Histoire of 1770 ) on the common core of human behaviour, on the impact of climate in a broad sense on character, and on the moral dangers of excessive travel, in Anthony Pagden, 'The Effacement of Difference: Colonialism and the Origins of Nationalism in Diderot and Herder', in Prakash, After Colonialism, pp. 131-5. Note also Diderot's rejection of slavery, and its racist basis in that 'atrocious extravaganza', the story of Cain (p. 139). Herder opposed colonialism (in a work translated and published in London in 1800 ) because of its effect of reducing cultural diversity while degenerating the colonizing nations: 'full blown bladders in human shape, lost to every noble or active pleasure, and in whose veins [literally] lurks avenging death' (p. 141).

51 Mark Harrison, Climates and Constitutions. Health, Race, Environment and British Imperialism in India, I6oo- 1850 (New Delhi 1999), esp. pp. 11-18.
} 
suggests that the development of the nineteenth-century sense of ethnicity depended on what he calls deep analysis as opposed to surface distinctions. The latter were the kinds of distinction that were the basis of the categorization devised by Linnaeus. By contrast, a deep categorization depended upon biological characteristics. Harrison suggests that for many the starting-point (appropriate equally to Christian and to Enlightenment thought) was an assumption of common humanity that differed through reactions to circumstance, a surface distinction. But, if, say, an enervating climate predisposed the people of hot countries to stagnation and fatalism, would a European last long in the tropics without being corrupted? Could standards be preserved, living in the heart of darkness? (To be fair to Conrad, that reference is not entirely apt, in that his narrator, Marlow, specifically equates the darkness with a lack of civilization rather than with place, and his tale is at best ironic or equivocal about the benefits of an efficient imperialism, a point to which I shall return.) Nonetheless, as Harrison explains, in order to justify a tropical European empire it was necessary to have a different, deeper theory, that explained how Europeans would retain their supposed superiority. Accordingly, it was decided, it was not the bracing climate of the North which made them enterprising, but their inherited character; and thus the East and the South could be conquered and reformed. We shall see that, as it developed, this idea would threaten Arthur's project.

Modern explanations of difference evolved over perhaps a couple of hundred years and did not emerge fully as a doctrine of race until the middle of the nineteenth century. In other words, Arthur's Englishness took advantage of a window of opportunity that would never close but which would be narrowed. For his part, Richard Blechynden was constantly aware of difference, but not just between Europe and India; also within categories of people according to behaviour and beliefs. He distinguished between Frenchmen of the ancien régime and French democrats and free thinkers whom he despised and distrusted. But if Frenchmen could change their nature by their actions so it was possible for a boy born in Calcutta to be translated into a true Englishman, defined by mores and conduct. Blechynden had his own theory of patriotism too, that it was a natural attachment expressed as a series of circles of interest and partiality building out from one's immediate family. ${ }^{52}$ His plan for Arthur and the others was to catch 
them within that net, by making the circles concentric: kinship with an English father would be reinforced by ties with English relatives and thus with all the English.

Already in the late eighteenth and early nineteenth centuries there were certainly stereotypes of lazy natives and upright Englishmen. Indian and European too were meaningful labels, but they were still somewhat inchoate and inconsistent. As said, Lockean self-creation mattered, and by that token, Arthur, a boy of mixed race, could be transformed by education and partly by class. He could be John Halifax Gentleman avant la lettre - made by manners and not blood. ${ }^{53}$ In Mrs Craik's novel, Halifax was orphaned but Saxon in appearance and allegedly the son of a gentleman, and yet 'he was indebted to no forefathers for a family history, the chronicle commenced with himself, and was altogether of his own making. No romantic antecedents ever turned up, his lineage remained uninvestigated, and his pedigree began and ended with his own honest name.' Moreover, at the end of the novel, he died peacefully, on 1 August 1834 , the very day when 'honest old England had lifted up her generous voice, had paid down cheerfully her twenty millions, and in all her colonies the Negro was free.' John Halifax thus exemplified the essential equality of all men, known by their deeds and not their blood, and it was aristocrats who were dissolute and unreliable. So too in Ricardian economics. This was apt as explorers and adventurers pursued trade and empire, and when individual, local entrepreneurs were forging the British industrial revolution-as they would the American, to the same refrain.

However, it was less fit for the age of the corporation, or its social equivalents, the community and the nation. Thus the ideal was increasingly clouded by racial stereotypes and distinctions, which relied once again on intrinsic qualities, as would Social Darwinism. By the 1830s, Arthur would already have been an Anglo-Indian, put in a category with known characteristics. It is not that self-improvement disappeared but it came to be enacted within more complicated constraints. The muddle of Oliver Twist makes this plain: the workhouse boy steeped in crime turns out to have been a gentleman by birth. By contrast, in Great Expectations, Dickens seized on the ambiguities between the appearance and the reality of character, class and ancestry (in regard to Pip, Joe, Magwitch, Estella and so on). A more telling literary connection, however, is that of Thackeray. His Eurasian

${ }^{53}$ Mrs Craik [Dinah Maria Mulock], John Halifax, Gentleman [1857] (London \& Glasgow n.d.), pp. 16-17 and $5^{13}$. 
half-sister, Sarah, married another Blechynden, and Thackeray himself benefited from Blechynden trust funds to pay off gambling debts in England. He admitted to feeling some guilt about Sarah after her death in 1841 , and once had an Anglo-Indian niece to stay with him in England. But he seems never to have acknowledged or admitted the connection thereafter; and it is argued that the frequent references to mixed race in his works are marked by animosity. ${ }^{54}$

Deciding on the character of Eurasian people was clearly relevant to this transition between the autonomous individual and the type. Mixed race posed greater difficulties the deeper or more intrinsic categorization became. Such hybrids contradicted the sense of binary or unified categories, so that 'Anglo-Indian' or 'Eurasian' was needed, and had to be given its own essential, defining qualities. Arthur could be English by upbringing and conduct, according to the false syllogism: these are English qualities; Arthur has these qualities; therefore Arthur is English. But, alternatively, there was this proposition: all Indians are unreliable; Arthur is part Indian; therefore Arthur cannot be wholly trusted. So it was that British officialdom came to see AngloIndians as suitable only to be subordinates, a standing very different from that secured by such Calcutta luminaries as the ship-builder, James Kyd (already mentioned), who ironically was a founding-father of the Anglo-Indian community. These small examples and particular cases, therefore, have a wider resonance, defining a possibility that seems to have been less complicated before about 1830 than it was afterwards. Incidentally, it might be thought that becoming English as Arthur did is not without interest to issues of identity for both diaspora and host communities to the present day.

\section{Corruption, identity and empire}

In what did Arthur's Englishness consist? Given the emphasis on education and self-creation, it had to be a specific set of characteristics, behaviours and attitudes. Thus his story also tells us something about the Calcutta of his day, and about British self-perception. In the case of the Blechyndens, 'English' and 'British' were largely interchangeable (though of course they were still distinct for others, especially the

${ }^{54}$ I am indebted for these points toJoe Lockard (http://soc.berkeley.edu/ lockard), citing George P. Davies, Catherine Porter and Thackeray's letters. 
Scots who were so important in Calcutta) $;{ }^{55}$ and thus the standards which made Arthur English were, in part, also the markers of that Britishness that justified imperialism. They would also be enlisted as intrinsic qualities, as race theories developed.

The context was that, from the 1760 s to the 1840 , the East India Company was developing its own notions of public service. Peter Marshall has documented both the making of what he called East Indian Fortunes and the attempts to regularize Bengal administration. ${ }^{56}$ Contrary to common opinion, and despite the excesses of many individuals, Company servants recognized, from their first exercise of political power, that the Company needed to take a long view rather than a quick profit. Amidst public and private greed, they conceded that it had a duty of care to its Indian subjects. The famous indictments by Burke and the attempted impeachment of Warren Hastings were party-political skirmishes rather than the introduction of a great new principle. Hastings agreed with Burke that government bore responsibilities, and, despite a ruthless pursuit of private and Company profit, he also supported very many initiatives that were unlikely to pay directly, but which accorded with post-Enlightenment theories on government in society. His or his contemporaries' concerns with landed property, legal rights, education, and scholarly or geographical explorations all fitted some idea or other of the proper conduct of states. They reflected an increasingly competitive image of enlightened rule-so Prussia one day, England and France the next, and tomorrow Bengal.

Among these developments was a demand for public efficiency. There arose new definitions of corruption. In rhetoric if not practice, it was now increasingly seen to be 'corrupt' for anyone holding public office to use it for private profit or advantage. ${ }^{57}$ There arose too a renewed professionalism, whether in general or in specialist services. Even in advance of the demand for formal qualifications, many official and civil tasks were being reserved, at least in theory, to those with proven competence in them. From clerks to surgeons, more of the

55 Tom Tomlinson reminded me that this caveat was necessary.

${ }^{56}$ P. J. Marshall, East Indian Fortunes (Oxford 1976), and see note 3 above.

57 The idea was linked to the separation of crown and parliament, and the slow growth of civil government, with milestones in the sixteenth and seventeenth centuries, and before, as well as in the eighteenth. Pepys's diary and career illustrate the point. In India, this notion of service was not unique to European administration, but ultimately it could not advance far until power was objectified in the state, as opposed to the ruler's person, whether Company satrap, or nawab, or zamindar. 
employees of the state and the servants of the public were being publicly trained-that is, made fit to do their 'duty'. Abroad, the experience of facing the unfamiliar added impetus to this demand for expertise. Empire made it desirable to possess knowledge rather than to rely only on native informants; and that meant policing the possessors as well as the subjects.

The usual assertion is that these changes provided arguments to excuse the known injustices and abuses of empire. It may be, however, that the relationship between the abuses and the arguments was more direct. One could say that the examples of Europeans 'corrupted' by India helped generate the technical and bureaucratic improvements, and the rhetoric of duty and responsibility, that were deployed to justify empire-in some cases by Indians as well as the British. In this final section, therefore, I will offer Arthur Blechynden's Englishness as a case study of this process. Some of the imperial ideas of European superiority and duty he clearly internalized, either in the face of obvious corruption, or because of it.

At the time, public and private interests remained blurred, despite the reforms of Hastings, Cornwallis and Shore and the imperialism of Wellesley. Many individuals in the Company's employ still profited on their own account, both honestly and dishonestly, from undertaking the Company's work. As surveyors also responsible for roads and drains, the Blechyndens were well-placed to observe how Company materials and workers were deployed in the private houses and gardens of influential officials, including judges. Richard Blechynden had suffered when the costs of Calcutta's new Circular Road were grossly inflated in order to conceal the private profits made from the supply of materials for building Wellesley's excessively-expensive Government House. The Police Office, responsible inter alia for public works and road maintenance, seems to have been particularly irregular. As Arthur wrote in his diary in 1807 , the magistrates were 'so slow in their operations, and so lazy and negligent in their duty' that business could hardly be carried on, works were continually delayed, no justice was to be obtained, and bribery was rife. In May 1809 the accounts for December 1808 had still not been made out, though payments were continuing in a haphazard way once approved by the Auditor-General, whose requests for explanations, however, tended to go unanswered. ${ }^{58}$ The chief agents of the inefficiency were two of the Justices, Martin and

${ }^{58} \mathrm{AB}$, 3o May 1809. 
Blacquiere.$^{59}$ Martin had long been notorious for his private life as well as the capriciousness and partiality of his legal judgments. Blacquiere was allegedly the 'corruptest man in the whole Settlement'. ${ }^{60}$ At one count he held fourteen offices, but allegedly was still grasping for profit. $^{61}$

Arthur's experience in this environment was a lesson in proper conduct, on not acting as some Englishmen did in India. He and his father had plenty of complaints about Indian judgment, reliability and workmanship, but it was European corruption that most held their attention. The years of Arthur's apprenticeship saw a struggle of power and principle, in the course of which he and his father redefined their own standards and character. A brief account of some aspects will demonstrate the point; the cases are those experienced by the Blechyndens but they exemplify a more general crisis in public life.

In the early years of the century, the magistrates began to withdraw aspects of work from their superintendent of roads. They entered into contracts for the maintenance of particular streets, and for the supply of materials, labourers and transportation. They professed to be trying to remedy problems of cost and supply, and to be relieving the superintendent of tasks he was too busy to perform. They were acting, they claimed, in the public interest. ${ }^{62}$ Various battles ensued over supplies and appointments. Posts were abruptly withdrawn from Blechynden's men-road peons, scavengers and so on-who were replaced by new people who would answer only to the magistrates or their agents, though the superintendent remained technically responsible for them and their work. ${ }^{63}$ Blacquiere's men took to insulting Blechynden's servants, jeering that their master's job had been taken away from him. ${ }^{64}$ His position became virtually untenable, while the roads deteriorated, and floods threatened because of unrepaired drains. Blechynden was held to account, while being denied the means to provide remedies. ${ }^{65}$

Power was arrogated in particular by a constable, Hessen, a Dutchman. The constable was supposed to be employed to assist the superintendent, but Hessen obstructed Blechynden at every

\footnotetext{
${ }^{59} \mathrm{AB}, 22$ April 1807.

$60 \mathrm{AB}, 16$ July 1811 .

${ }^{61} \mathrm{AB}, 7$ July 1812.

${ }^{62} \mathrm{AB}, 8$ October 1808,16 July 1811.

${ }^{63} \mathrm{AB}, 1$ December 1809 .

${ }^{64} \mathrm{AB}, 15$ July 1811.

${ }^{65} \mathrm{AB}, 1$ July 1811.
} 
turn, refusing his requisitions for supplies. He was a 'creature' of Blacquiere's. ${ }^{66} \mathrm{He}$ was also clerk to a public market, where he collected dues and ground rents. He was said to make appointments to posts carrying a stipend of 4 rupees a month, in return for bribes of at least 20 rupees; he refused one offer of four monthly instalments of 8 rupees. ${ }^{67}$ He took control of the Company's carts, which he could use for private purposes, and of the certification of the numbers of workers and the quantities and quality of materials, which he or his associates had supplied. He was thought to be pocketing 10 or 20 rupees a day just from unclaimed property recovered from the streets and supposed to be sold for the public purse. He was certainly obtaining income from those who were making encroachments on the public roads, the prevention of which was a major preoccupation of the superintendent. Blechynden found his men resisted by an insolent insistence that some illegal building or other had been sanctioned by Hessen. The constable himself received $5^{\circ}$ rupees a month for allowing illegal trading on part of the Circular Road. ${ }^{68}$ More lowly employees too took advantage: the scavengers (or street cleaners) became notorious for their demands, for 'tricks upon tricks', impositions sometimes so glaring that investigation could not be avoided. But always, according to the clerk to the Police Office, Blacquiere ensured that the inquiries were dropped. ${ }^{69}$

The confusion in the Office no doubt owed much to the indolence and the other occupations of the magistrates. But it was also convenient for them. The contract system was instituted in the face of Blechynden's repeated recommendation that direct working and a single line of authority be instituted, a reform again suggested by others, and again not implemented, in 1811 . The magistrates' motive was plain: the contracts that were issued were in effect with Martin and Blacquiere themselves. Martin's agents included one 'Sunkur Mundal', who supplied bullocks of very poor quality and made 'a good deal of profit' for Martin. ${ }^{70}$ Others of his associates supplied labour. The workers' pay was kept months in arrears, until they refused to work, while the daily returns recorded more workers than were employed. From the resulting margins, the contractor paid Martin. ${ }^{71}$

\footnotetext{
${ }^{66} \mathrm{AB}, 14$ July 1810.

${ }^{67} \mathrm{AB}, 16$ July 1811.

${ }^{68} \mathrm{AB}, 18$ July 1811.

${ }^{69} \mathrm{AB}$, 2 January 1812.

${ }^{70}$ AB, 22 April 1809 , 1 May 1809.

71 AB, 19 May 1809 .
} 
Blacquiere supplied the bricks and gravel for the roads, a corrupt connection that caused comment but no action from his superiors. He had promised an improvement in quality, but what he supplied was worse than before, often so bad as to be unusable. ${ }^{72}$ In time, his men also took over the maintenance, at first as said for particular roads-a contract for the Kidderpore Road, example, given to one 'Kinker Banarjeah'. This man later revealed many of Blacquiere's secrets to the Blechyndens in revenge for being excluded from new arrangements with Hessen, fobbed off with a retainer of $5^{\text {o rupees }}$ a month, a fraction of his former profits. ${ }^{73}$ Later when Blacquiere discharged Blechynden's men and replaced them with his own, his take-over of general road maintenance opened up further possibilities for fraud, as earlier for Martin. As said, there was no independent check on any of the measurements. In July 1812 , Arthur made a rough assessment of the materials stored at the riverside landing places, and concluded that only a small fraction of the quantities being charged for even existed in the town. ${ }^{74}$

Blacquiere's abuses allegedly extended wherever he had influence. As a justice of the peace he was said, by the Eurasian Charles Reed, who threatened to expose him, to have conspired to protect one of his associates from punishment, in a typically elaborate scheme to thwart the Sadr Diwani Adalat. That court had forced him to convict one of his associates, whom he had then incited to take out a complaint against himself, with the Supreme Court, for false imprisonment. ${ }^{75}$ Similarly, at the Alipore jail, the European chief warder reported to Blechynden that he could do nothing against Blacquiere's people, led by a Bengali 'who does everything as he pleases', consorting with the leading prisoner, monopolizing all the jail's supplies, and giving his orders daily to the other guards, sitting on a carpet 'like a chief'. Many prisoners were dying from neglect, while the jail's surgeon, Dr Young, merely took his salary and came occasionally to the Bengali warder's house, with 'great hauteur', to write the death certificates. ${ }^{76}$

Richard Blechynden naturally rallied his friends to try to remedy the situation in which he found himself. He dropped hints and snippets of information in what he hoped were receptive ears at Government

\footnotetext{
$72 \mathrm{AB}, 3$ April 1811, 11 May 1811 , 17 July 1811.

${ }^{73} \mathrm{AB}, 1$ July 1811.

${ }^{74} \mathrm{AB}, 6$ July 1812.

${ }^{75} \mathrm{AB}, 9$ \& 18 July 1812 .

${ }^{76} \mathrm{AB}, 26$ May 1811.
} 
House ${ }^{77}$ His strongest threat was to create a storm by writing officially to the Governor General. But there were risks. His complaints could rebound on himself. Just as Blacquiere and Martin manipulated the law and their office to protect their men, so too they could be supported by the high Company officials, often their friends and ship- or school-mates. Both men were repeatedly confirmed in their offices in the face of barely-concealed scandals. Blacquiere, who enjoyed long life, was celebrated by his later contemporary, the Reverend James Long, merely as the 'oldest [European] resident' of Calcutta. ${ }^{78}$

In recording the abuses in his diary, Arthur was expressing a private indignation-his father's interest was in jeopardy, and he himself was being denied office as his deputy. He still expected a post to be created for him, as his father's son and through influence. On the other hand, as befitted this transitional period, he justified his expectations by claiming that he was well-qualified after a formal apprenticeship, and that a need had been demonstrated through his having undertaken the work unpaid. In his criticisms of the magistrates, moreover, he also appealed to the public interest. He sought probity as professed in the Company's own declarations, and as promoted by activists and critics such as Charles Reed. Both Blechyndens repeatedly expressed a confidence that justice would be done, and that villainy would not pay in the end. The terms of Arthur's indignation are significant. 'It is lamentable', he noted, 'to reflect that such iniquities are suffered to pervade almost every department' of the Police Office. ${ }^{79}$ Referring to Blacquiere, 'How much longer', he asked, 'will the strong arm of friendship continue to support his abominable system calculated solely to benefit a Magistrate and his creatures'?80 'How improper of him', he wrote on another occasion, 'to make his duty subservient to his interest'. ${ }^{81}$ 'How infamous!', he exclaimed, of Martin's conduct, 'How degrading to the character of a British Justice of the Peace!" ${ }^{82}$ Two things are plain: the problem was un-British conduct, as Dadabhai Naoroji would later argue, and the remedy was regular administration.

In short, a rhetoric of public service existed, and was firmly believed against the odds by at least one young man in Calcutta. It was

${ }_{77} \mathrm{AB}, 7,8$ \& 9 July 1812.

${ }^{78}$ James Long, Calcutta and its Neighbourhood: History of Calcutta and its People from I 69o- I 857 (ed. Sankar Sen Gupta: Calcutta 1974), p. 209.

${ }_{79} \mathrm{AB}, 2$ January 1812.

${ }^{80} \mathrm{AB}, 6$ July 1812.

${ }^{81} \mathrm{AB}, 14$ July 1810.

${ }^{82}$ AB, 19 May 1809 . 
promoted, as said, by the Company's rules and sanctions. These were inflected with ideas of due process and individual responsibility, which formed the bedrock for concepts of justice and propriety. When a Eurasian, William Grey, the Blechyndens' coachman, ran over an old woman, who later died, he, and also two attendants who bore no responsibility, were imprisoned and then fined on the orders of Martin. He claimed it was to oblige Richard Blechynden-who (though not above inflicting collective punishments on his servants) was displeased that Martin had judged him 'by his own standard'. The point was that Martin should have opened an inquest. The finding would have been 'accidental death' and Blechynden would then have had to compensate the woman's family. ${ }^{83}$ Martin thought it more convenient to punish the innocent employees. Blechynden, denied 'due process', still accepted 'responsibility', and sent money to the woman's family.

The Blechyndens' high-mindedness seems to have had nothing to do with calls for 'liberty', whether in Putney, North America or France, though an echo of those arguments undoubtedly influenced the emphasis the Company placed on responsible conduct by its 'private' unaccountable government in India, in response to Burke and other critics. This forced it to espouse a social and ethical code that was in turn linked to the development of public policy, official duties, and definitive law. The Blechynden's take on this, however, shows how it also contributed to the definitions of what English- and Britishness meant. The definitions emerged out of the political exigencies of eighteenth-century Britain, and from various conditions, as discussed by others, ${ }^{84}$ but clearly had their counterparts in India. Arguably, the experience of India gave a particular edge to this conjunction of ideas.

Examples of 'corruption' stimulated among its witnesses and victims new standards of public service, related to ideas of state responsibility. These ideals were constructed in opposition to what were thought to be Indian conditions and character, but also in the context of continuing fears of the corruption of Indian experience. As said, Richard Blechynden repeatedly bemoaned-without ever resistingthe lack of standards which led him and most of his fellows to consort with women who were not their wives. At the same time, in public, he meticulously observed the various protocols that protected the outward forms of propriety. Similarly, the East India Company, facing its parliamentary critics, professed upright conduct in order to justify

${ }^{83} \mathrm{RB}, 4$ July 1810.

${ }^{84}$ Colley, Britons. 
its governmental role and to control the worst excesses of its servants: regulation and censorship were the more necessary in such a corrupt and grasping environment, which led to the development of complex codes of practice and the start of slow expansions of the state's role. The Company thus communicated an everyday morality, internalized by the many Arthur Blechyndens of the empire, and by many Indians too, as part of a discourse of rights. They even provided an argument for an acceptance of empire, and indeed of curbs upon English liberty and especially on the poor. And this was partly because Company morality did not reflect any consistent contrast between British and Indian standards of honesty and service, as the cases of Martin and Blacquiere demonstrate. Practice was often very different from rhetoric. But then, in defining national characteristics, what is said often matters more than what is done. Hypocrisy, self-delusion and identity are frequent bed-fellows.

John Malcolm, celebrated Indian civil servant, and protègé of Governor-General Wellesley, elevated all this, around the same time, into a prospectus for British rule, in his Sketch of the Political History of India. ${ }^{85} \mathrm{He}$ attributed British conquest to the self-defence of the Company's territories against its neighbours and to the 'rapacity and ambition of ... [its] own servants'. Not for him the excuse advanced by slightly later historians of rescuing India from anarchy. Malcolm then advocated goals and methods that were at the same time conservative and quasi-liberal. The Company needed, he wrote, the 'unshaken firmness and dignified spirit of an absolute, but tempered rule, [combined] with the most unceasing attention to the religious prejudices and civil rights of our Indian subjects, whose condition it must be our continual study to improve, in the conviction that our Government ... cannot be permanent, but by their means'. Securing British territories through political non-interference had proved 'unwise and impracticable', and the force of an effective army was necessary. (Its Indian personnel and their families also should be rewarded.) On one hand, a civil code of regulations, and laws 'founded in a spirit of attention to the usages and religion of the different tribes of India', would attach to British rule those devoted to peaceful occupations. On the other hand, though European settlement was not to be encouraged, European example would help 'advance the natives of India in every branch of useful knowledge'. In short, India was to be

${ }^{85} \mathrm{John}$ Malcolm, Sketch of the Political History of India ... (2nd ed. London, 1811 ). For the following, see pp. $4,9,45^{8-62,} 4^{68-75}, 47^{8}$ and $5^{12-30 .}$ 
ruled so as to 'introduce civilization', for example through the liberal arts and public works, and also to advance the happiness and prosperity of Indians, rather than in the exclusive interest of Britain.

Implicitly this was constructing an imperial Englishman-his sense of duty, his probity, his civilizing mission. It was just what Arthur was making of himself. This reinforces Anthony Pagden's comment, that 'the British insistence that their empire was essentially dedicated to improving the condition, the "liberty," both political and economic, of all with whom it came into contact, was not a mere sentimental reflection nor a simple ideological camouflage-although it also served both those functions. It was an essential component of English and later, with still greater emphasis, British identity. ${ }^{86}$ Conrad, another self-constructed Englishman, put it more ambivalently, linking classical and modern empires as in the eighteenth century, and also the contrasting values of the East and the West: 'I was thinking of very old times, when the Romans first came here...', said Marlow, on a ship off the south-east coast of England, '...We live in the flicker-may it last as long as the old earth keeps rolling! But darkness was here yesterday.' He commented on how the Romans would have been appalled and fascinated by the primitive abominations of ancient Britain, but then went on, 'lifting one arm from the elbow, the palm of the hand outwards, so that, with his legs folded before him, he had the pose of a Buddha...',-'Mind, none of us would feel exactly like this. What saves us is efficiency-devotion to efficiency.... The conquest of the earth, which mostly means taking it away from those who have a different complexion or slightly flatter noses than ourselves, is not a pretty thing when you look into it too much. What redeems it is the idea only... and an unselfish belief in the idea-something you can set up, and bow down before, and offer a sacrifice to ... ${ }^{87}$

${ }^{86}$ Anthony Pagden, 'Afterword: from Empire to Federation', in Rajan and Sauer, Imperialisms, p. 262. I was pleased to read this, as a motto for this section, after my paper was written.

${ }^{87}$ Joseph Conrad, Heart of Darkness [1902] in Heart of Darkness and Typhoon, London 1976), pp. 12-13. Despite his extensive study of Conrad, Edward Said, in Culture and Imperialism (London 1994), offers a limited reading of this passage, ignoring the comparison of Marlow with the Buddha, and equating 'efficiency' with rationality and exploitation (p. 7o), and later with 'salvation' or 'redemption' and 'a structure that completely encircles' (pp. 81-2), instead of also defining the 'idea' as Conrad does, with regard to civilization and hence improvement - that is, as actively keeping back the 'darkness'. Said is eloquent, however, on the 'consolidated vision' or pervasiveness of empire in conceptions of the British by themselves. 
The same idea was being framed in India around the turn of the nineteenth century, and served an imperial purpose. In a celebrated essay, Bernard Cohn once concluded that British officials, recruited to serve in India at an early age, began with an 'idealized adolescent view of their own society and culture' that 'tended to become fossilized'. ${ }^{88}$ Without wishing to contradict Cohn (after all, ideas circulated), this paper makes the reverse observation. Arthur, as an adolescent, adopted ideals and an identity that were being actively projected in India, to justify foreign rule and to limit and manage autocratic government. They would be translated back to England by others, to join and reinforce similar notions of different origin.

${ }^{88}$ B. S. Cohn, 'The British in Benares. A Nineteenth Century Colonial Society', Comparative Studies in Society and HistoryIV, 2 (January 1962), p. 199. 
